\title{
Dampak Kabut Asap terhadap Kinerja Usaha Pedagang Pasar di Kota Rengat Kabupaten Indragiri Hulu Provinsi Riau
}

\author{
Ivalaina Astarina $^{1 *}$, Syahmardi Yacob², Febblina Daryanes ${ }^{3}$, Khusnul Fikri ${ }^{4}$, A.F. Ahmad Ramadhan ${ }^{5}$ \\ ${ }_{1,4,5}$ Program Studi Manajemen, Sekolah Tinggi Ilmu Ekonomi Indragiri Rengat \\ ${ }^{2}$ Fakultas Ekonomi dan Bisnis, Universitas Jambi \\ ${ }^{3}$ Fakultas Keguruan dan Ilmu Pendidikan, Universitas Riau

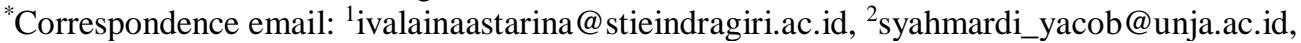 \\ ${ }^{3}$ febblina.daryanes@lecturer.unri.ac.id, ${ }^{4}$ khusnul_fikri@stieindragiri.ac.id, ${ }^{5}$ afahmad.ramadhan@gmail.com
}

\begin{abstract}
The purpose of the research in IIS to know and analyze the impact of the haze on the performance of business traders market. This research belongs to the type of descriptive research. Descriptive research that aims to describe, describe and analyse existing events and aims to obtain information about the impact of haze in accordance with existing theories. Data collection method through dissemination of questionnaires and questions answered. The population in this study is the market merchant of Rengat City. Determination of sample count of 100 respondents/market trader. The data analysis technique used to analyze this research data is to be descriptively used statistical analysis in the form of a percentage formula because its purpose is to see the trend of the indicators of each variable and the research is only aimed to describe the reality in the field is not to be seen relations or comparisons. In this study, researchers used Likert measurement scales. The Likert scale relates to a statement about a person's attitude toward something. The results of this study can be concluded that: (1) The health of the market traders of the city of Rengat is interrupted because of the thick haze that affects the trading activity itself. (2) The income of market traders in the city of Rengat is decreasing due to declining people's desire to shop in the market due to the worry of being exposed to haze which can cause ISPA disease and other health disorders. (3) The market environment of the Rengat is affected by the smoke of the daily Trader's life. Usually traders have already held their trades starting from the beginning of the morning, because the haze of most traders often come late to the market (overdo). (3) The education of students from the family of market traders in the city of Rengat is also affected by the haze so that it must be dissolved until normal weather conditions are back. Because of this, students have a lot of missed material and have to force themselves to pursue the lag by adding hours and learning tasks that are much beyond the student's thinking capacity.
\end{abstract}

Keywords: haze; Business performance; Market traders

\section{Pendahuluan}

Musim kemarau yang melanda Indonesia pada tahun 2019 terjadi dalam rentan waktu yang relatif lama, serta memberi dampak negatif bagi pertumbuhan dan perkembangan ekosistem dunia termasuk manusia. Dilansir dari situs liputan6.com onlie (Harsono 2019:30 Juli), berdasarkan data Badan Meteorologi, Klimatologi dan Geofisika (BMKG), musim kemarau melanda wilayah Indonesia mulai bulan Juli hingga Oktober 2019. Berbeda dari tahuntahun sebelumnya, BMKG melaporkan, bahwa musim kemarau yang terjadi pada tahun 2019 akan jauh lebih kering. Kemudian dilansir dari situs regional.kompas.com online (Tanjung, 2019:15 September), BMKG memprediksi musim kemarau masih berlangsung hingga bulan Oktober 2019. Hal itu diungkapkan oleh Kepala Pusat Meteorologi Publik BMKG Fachri Rajab, untuk Riau, diperkirakan kemarau sampai dengan pertengahan Oktober, dan musim hujan di pertengahan bulan Oktober 2019. Dalam kurun waktu tiga bulan (Juli 2019-September 2019), kemarau telah melanda Provinsi Riau termasuk Kota Rengat Kabupaten Indragiri Hulu. Kondisi tersebut telah menyebabkan dampak kekeringan sungai dan kegersangan lahan yang berkepanjangan. Fenomena yang terjadi karenanya adalah kebakaran lahan dan hutan (Karhutla), baik yang terbakar maupun sengaja dibakar oleh oknum yang tidak bertanggung jawab karena ingin membukan lahan perkebunan secara instan dengan memanfaatkan musim kemarau. Kebakaran hutan menurut Surat Keputusan Menteri Kehutanan No.195/ Kpts-II/1996 didefinisikan sebagai keadaan di mana hutan dilanda api sehingga mengakibatkan kerusakan hutan dan hasil hutan yang menimbulkan kerugian ekonomi dan lingkungannya.

Banyaknya kebakaran hutan dan lahan yang terjadi karena akumulasi dari titik panas di Provinsi Riau, Jambi dan Sumatera Selatan yang semakin bertambah. Dari laman inews.id online (Ikhbal, 2019:18 September), dapat diketahui bahwa jumlah titik api per tanggal 18 September 2019 yang terpantau Satelit Terra Aqua di Provinsi Riau Riau, Jambi dan Sumatera Selatan sejumlah 1.200 an. Titik api (hotspot) di berbagai wilayah berkembang menjadi kebakaran, akibat dari kebakaran hutan dan lahan itu sendiri adalah punahnya ekosistem hutan dan lahan. Pemerintah pusat maupun daerah telah melakukan pencegahan dan tindakan pemadaman titik api, namun masih dapat dikatakan lamban dan belum maksimal serta tidak tegas dalam pengambilan kebijakan. Hasil dari kebakaran hutan dan lahan telah menyumbang kabut asap yang semakin hari semakin tebal sehingga memperburuk kualitas udara mencapai level 
500 (berbahaya) (Raharjo, 2019:23 September). Hal ini ditandai dengan perubahan ruang angkasa yang biasanya cerah dan berwarna biru telah menjadi merah karena diselimuti asap hingga akhir bulan September tahun ini. Kabut asap yang melanda Provinsi Riau, Jambi, Sumatera Selatan dan Kalimantan juga telah menyebar ke berbagai wilayah Indonesia bahkan sampai ke negera tetangga seperti Singapura dan Malaysia. Dan tentunya memberi dampak negatif terhadap berbagai sektor kehidupan masyarakat, seperti sektor kesehatan, pendidikan, pertumbuhan ekonomi, lalu lintas perdagangan dan jasa pelayanan transportasi darat, laut dan udara.

Bagi manusia, udara segar adalah kebutuhan yang mendasar untuk bernafas. Udara salah satu nikmat terbesar yang dikaruniakan Allah kepada setiap makhlukNya khususnya manusia. Kabut asap sangat mempengaruhi ketersediaan udara segar tersebut sehingga berdampak terhadap menurunya kesehatan masyarakat yang ditandai dengan meningkatnya jumlah masyarakat yang terserang penyakit Infeksi Saluran Pernapasan Akut (ISPA), bahkan sampai menyebabkan kematian bagi sebagian balita karena susahnya menghirup udara segar. Selain itu, udara segar dan cuaca cerah juga merupakan kebutuhan utama dan penunjang lainnya yang sangat dibutuhkan masyarakat dalam melakukan berbagai aktivitas perekonomian seperti jual-beli (perdagangan). Dampak kabut asap yang tebal telah menurunkan berbagai aktivitas jual beli bagi pedagang pasar. Kontak jual beli jadi terputus karena tidak lengkapnya syarat jual beli itu sendiri, seperti ada penjual tapi tidak ada pembeli. Dengan kata lain, kuatnya keinginan para pedagang untuk menjual barang dagangannya di pasar tidak diiringi dengan tingginya minat para pembeli menuju pasar untuk membeli berbagai kebutuhan rumah tangganya. Dengan demikian, aktivitas jual beli di pasar mengalami penurunan yang drastis yang intensitas perdagangan biasanya rutin bertransaksi setiap hari, karena adanya kabut asap menjadi berkurang hingga satu kali dalam seminggu atau bahkan dalam hitungan bulan saja. Kondisi sedemikian rupa sebagaimana yang dialami oleh pedagang pasar di Kota Rengat berdampak ke berbagai lini kehidupan masyarakat termasuk pedagang itu sendiri. Dari berbagai dampak yang dihasilkan tentunya dapat mempengaruhi jumlah pendapatan pedagang. Sementara pedagang juga merupakan bagian dari masyarakat konsumtif yang artinya mereka juga sebagai masyarakat pembeli yang perlu memenuhi kebutuhan hidupnya. Dengan demikian, lajunya perputaran ekonomi menjadi terhambat karena kabut asap yang telah melanda kota Rengat.

Berbagai dampak negatif terjadi dari fenomena kabut asap, diantaranya: (1) Kesehatan masyarakat (Li et al., 2016; Kochi et al., 2010; Reid et al., 2016; Buka et al., 2006; Liu et al., 2016; Putri, 2015). (2) Pendapatan (Luo et al., 2014; Noor, 2007; Putri, 2015; Lang et al., 2008). (3) Lingkungan (Liu et al., 2016; Putri, 2015), (4) Pendidikan (Xu \& Zhou, 2018; Zweigh et al., 2009) dan masih banyak dampak negatif lainnya yang terjadi. Namun peneliti membatasi dampak kabut asap terhadap empat aspek tersebut. Lang et al., (2008) menyimpulkan bahwa knowledge about the potential consequences of air pollution on cognitive abilities is more limited. Poor cognitive function may have profound social, economic and health implications. Kemudian dalam penelitian Li et al., (2016) menyatakan bahwa air deterioration caused by pollution has harmed public health. Dalam beberapa Dekade mendatang kebakaran hutan diperkirakan akan menimbulkan ancaman yang semakin besar. Asap sisa hasil pembakaran hutan mengandung berbagai macam polutan udara diantaranya Karbonmonoksida (CO), Nitrogen Oksida, Ozon, Partikel (PM) yang dapat membahayakan kesehatan masyarakat (Liu et al., 2016; Reid et al., 2016), seperti gangguan pernapasan, bronchitis, pneumonia, asma, dan kardiovaskular (Duran, 2014), serta keracunan karbonmonoksida. Selain itu, artikel dimasa kini juga sedang menyoroti pengaruh polusi udara terhadap kematian, gangguan kehamilan, kekurangan vitamin D, dan perubahan sistem kekebalan tubuh pada anak-anak. Selain itu kabut asap juga menyebabkan problematika dalam dunia pendidikan, lebih dari tiga pekan siswa-siswi di Kabupaten Indragiri Hulu diliburkan menyebabkan ribuan siswa-siswi ketinggalan pelajaran. Selain itu, pasca kabut asap masih banyak siswa yang tidak dapat masuk ke sekolah dikarenakan masih menderita gangguan pernapasan, yang menyebabkan perolehan nilai siswa menjadi menurun. Menurut Zweigh et al., (2009) terdapat hubungan antara tingkat polusi udara dengan skor ujian siswa, semakin rendah tingkat polusi udara maka semakin meningkat perolehan skor siswa. Polusi udara dapat menurunkan kinerja akademik pada anak-anak. Terdapat empat mekanisme dimana polusi dapat mempengaruhi kinerja akademik: (1) Ketidakhadiran di sekolah karena sakit yang disebabkan oleh polusi, (2) Masalah kurangnya perhatian di sekolah karena penyakit yang disebabkan oleh polusi, (3) Kelelahan saat mengerjakan pekerjaan rumah karena sakit yang disebabkan oleh polusi, dan (4) Efek negatif langsung dari polusi terhadap perkembangan otak.

Berdasarkan pengamatan dampak kabut asap yang terjadi adalah: (1) Bertambah jumlah pedagang pasar yang menderita ISPA sehingga menurunnya layanan jual beli. (2) Menurunnya jumlah pembeli di Pasar Kota Rengat sehingga menyebabkan pendapatan pedagang semakin menurun sehingga pedagang lebih cepat untuk menutup kiosnya. (3) Berubahnya pola kegiatan masyarakat untuk beraktivitas di luar rumah karena takut bahayanya kabut asap. Diketahui bahwa sebelum kabut asap melanda, kondisi kesehatan pedagang pasar sangat baik, jumlah pembeli dan transaksi jual beli hingga sore hari sehingga pendapatan pedagang stabil dan banyaknya kegiatan masyarakat yang dilakukan di luar rumah. (4) Terganggunya aktivitas belajar dan mengajar di sekolah karena diliburkannya aktivitas belajar dan mengajar sesuai arahan pihak terkait. Berdasarkan fenomena-fenomena yang terjadi, oleh karena itu perlu dilakukan kajian akademis mengenai dampak kabut asap pada kehidupan pedagang pasar di Kota Rengat. Penelitian 
ini mengkaji dampak kabut asap terhadap kehidupan pedagang pasar. Kebaharuan penelitian ini adalah melanjutkan penelitian Putri (2015), hanya saja pembahasan dampak kabut asap tidak memasukkan pendidikan. Kemudian dampak kabut asap di Kota Rengat belum ada yang meneliti, dan memberikan pemahaman kepada masyarakat bahwa kabut asap memiliki dampak terhadap kehidupannya.

\section{Metode}

Penelitian ini tergolong pada jenis penelitian Deskriptif. Penelitian deskriptif yaitu penelitian yang bertujuan untuk mendeskripsikan, menggambarkan dan menganalisa kejadian yang ada serta bertujuan untuk memperoleh informasi-informasi mengenai dampak kabut asap sesuai teori yang ada. Metode pengumpulan data melalui penyebaran kuesioner dan tanya jawab. Menurut Nawawi (2012) metode penelitian deskriptif dapat diartikan sebagai prosedur pemecahan masalah yang diselidiki dengan menggambarkan/melukiskan keadaan subjek/objek penelitian (seseorang, lembaga, masyarakat dan lain-lain) pada saat sekarang berdasarkan fakta-fakta yang tampak, atau sebagaimana adanya. Populasi dalam penelitian ini adalah pedagang pasar kota Rengat. Penentuan jumlah sampel sebanyak 100 responden/pedagang pasar, dikarenakan jumlah populasi yang tidak terdata secara akurat dan juga tidak terbatas. Sesuai dengan pendapat Cooper dan Emory (1996) populasi adalah tidak terbatas, jadi sebuah sampel sebanyak 100 orang yang diambil dari populasi berjumlah 5.000 secara kasar mempunyai ketepatan estimasi yang sama dengan 100 sampel yang diambil dari 200 juta populasi. Teknik pengambilan sampel menggunakan accidental sampling. Menurut Sugiyono (2009), accidental sampling adalah teknik penentuan sampel berdasarkan kebetulan bertemu antara pedagang pasar dengan peneliti. Teknik analisa data yang digunakan untuk menganalisa data penelitian ini adalah secara deskriptif yaitu digunakan analisa statistik berupa formula persentase karena tujuannya adalah untuk melihat kecenderungan-kecenderungan indikator masing-masing variabel dan penelitian ini hanya bertujuan untuk menggambarkan kenyataan dilapangan tidak untuk dilihat hubungan atau perbandingan. Dalam penelitian ini, peneliti menggunakan skala pengukuran likert. Skala likert berhubungan dengan pernyataan tentang sikap seseorang terhadap sesuatu, misalnya setuju-tidak setuju, senang-tidak senang dan baik-tidak baik (Umar, 2005).

\section{Hasil}

Berdasarkan hasil penelitian di lapangan dapat diperoleh bahwa kesehatan pedagang pasar Kota Rengat relatif menurun karena terdampak kabut asap. Hampir dari $1 / 3$ pedagang terserang penyakit inspeksi saluran pernapasan akut tipe sedang-ringan, seperti batuk-batuk, alergi, iritasi mata, dan cepat lelah. Kondisi ini tentunya memberi dampak negatif terhadap pelayanan yang diberikan kepada calon konsumen, sehingga dapat menyebabkan penurunan daya transaksi jual beli. Namun dari hasil pengamatan, sebagian besar pedagang di Kota Rengat mengalami gangguan pernapasan, sekalipun sudah menggunakan masker penyaring udara kotor, tindakan itu belum terlalu efektif dan masih berdampak negatif terhadap kesehatan masyarakat dikarenakan kabut asap yang semakin menebal. Apabila dikaitkan dengan kerugian ekonomi masyarakat terdampak kabut asap relatif besar karena harus menyisihkan pendapatan jual beli mereka untuk alokasi biaya perawatan kesehatan dirinya dan juga keluarganya.

Penelitian ini sesuai dengan penelitian yang dilakukan oleh Liu et al., (2015) di mana hasilnya menunjukkan bahwa, "Wildfire can impose a direct impact on human health under climate change, and the potential health impacts of increasing wildfire activity on large numbers of people in a warming climate and the need to establish or modify US wildfire management and evacuation programs in high-risk regions. The study also adds to the growing literature arguing that extreme events in a changing climate could have significant consequences for human health." Secara garis besarnya dapat disimpulkan bahwa kebakaran hutan dapat memberikan dampak langsung pada kesehatan manusia. Meningkatnya aktivitas api karena perubahan iklim berpotensi terhadap penurunan kesehatan pada sebagian besar orang. Peristiwa ekstrem dalam iklim yang berubah dapat memiliki konsekuensi signifikan bagi kesehatan manusia. Senada dengan hasil penelitian Kochi et al., (2010) yang memaparkan hasil telaah pustakanya, yaitu "Based on the findings from this literature review, we identify the need for a better understanding of the effect of wildfire smoke on major and minor adverse health outcomes." Dengan kata lain, dari pandangan Kochi et al., (2010) dkk tersebut menjelaskan bahwa ada kebutuhan mendasar yang perlu dipahami tentang efek kabut asap bagi kesehatan yang dapat mendatangkan kerugian finansial baik dalam skala kecil maupun besar. Pendapatan pedagang pasar Kota Rengat yang terdampak kabut asap juga mengalami penurunan yang relatif drastis. Pendapatan maksimal para pedagang pasar perhari sebelum kabut asap $>800.000,-$, setelah terkena dampak kabut asap pendapatan para pedagang di pasar mengalami penurunan yang signifikan dengan rata-rata penerimaan perhari $<500.000,-$. Secara bulanan para pedagang pasar Kota Rengat biasanya dapat meraih pendapatan maksimal $>5.000 .000,-$ sebelum ada musibah kabut asap. Terjadi penurunan drastis ketika kabut asap mulai menebal, di mana penerimaan pendapatan para pedagang menjadi <2.500.000,-. Setelah diamati dan diteliti lebih lanjut, kondisi tersebut dipengaruhi oleh berkurangnya intensitas daya belanja masyarakat ke pasar Kota Rengat, karena merasa khawatir terkena serangan penyakit saluran 
napas akibat kabut asap yang sangat tebal. Kalaupun harus kemungkinan besar masyarakat yang berbelanja untuk keperluan mingguan atau bulanan saja.

Penelitian ini sesuai dengan penelitian Rismadani Putri (2015) yang mengemukakan hasil penelitiannya tentang pendapatan warga Tuah Karya yang terkena dampak kabut asap untuk pendapatan pokok/bulan yang mereka memperoleh hanya yaitu Rp 1.000 .000 - Rp 1.500.000/bulan, sedangkan pendapatan perminggu rata-rata mereka hanya mendapatkan Rp. 500.000 - Rp. 700.000 Selama kabut asap terjadi. Berbeda dengan Sebelum terjadinya kabut asap dimana pendapatan warga Tuah Karya lebih besar dibandingkan saat kabut asap terjadi bisa dilihat pendapatan perbulan sebelum terjadinya kabut asap mereka rata-rata berkisar Rp 4.000.000 - Rp 5.000.000/bulan, sedangkan pendapatan rata-rata warga Tuah Karya $\mathrm{Rp} 500.000$ dan pendapatan dari pekerjaan sampingan warga rata-rata memperoleh Rp 1.500.000 - Rp 2.000.000. Lingkungan di pasar Kota Rengat yang ikut tercemar karena kabut asap turut mempengaruhi aktivitas sehari-hari para pedagang. Sebagian besar dari pedagang mengalami kesulitan menjalani aktivitas perdagangannya. Dilihat dari kesibukan pedagang selama kabut asap relatif menurun dibanding sebelum adanya kabut asap. Sebelum terjadi kabut asap biasanya jam 5 pagi seluruh pedagang sudah menggelar lapak dagangan mereka di pasar. Tetapi, setelah kabut asap kian menebal hanya yang masih terlihat sehat yang datang berjualan ke pasar Kota Rengat, karena harus memenuhi kebutuhan hidup keluarganya sehari-hari, namun kedatangan pedagang di pasar sering terlambat karena dipengaruhi jarak pandang yang semakin dekat lebih kurang 100-200 M. Tentunya para pedagang tidak mau mengambil resiko lebih besar seperti terjadi kecelakaan di jalan raya akibat kabut asap menghalangi jarak pandang antarpengguna jalur lintas perjalanan.

Pendidikan siswa yang terdampak kabut asap di Kota Rengat sangat jauh berbeda dengan saat siswa belajar tanpa adanya kabut asap. Hasil penelitian ini memperoleh gambaran bahwa aktivitas belajar siswa di sekolah terkendala karena banyak diliburkan pemerintah terkait semakin pekatnya kabut asap yang melanda Kota Rengat, karena dikhawatirkan siswa akan mudah terserang penyakit ISPA. Dalam kondisi tersebut, siswa banyak ketinggalan materi pelajaran. Manakala sekolah sudah aktif kembali sedangkan guru ada yang memaksakan penuntasan materi ajar, maka hal itu akan berdampak pada perkembangan mental belajar siswa karena dituntut untuk belajar lebih banyak atau adanya penambahan jadwal jam pembelajaran secara sepihak. Akibat kabut asap, daya konsentrasi belajar siswa juga dapat dikatakan menurun karena menurunnya fungsi kesehatan tubuh karena terpapar kabut asap, sehingga mempengaruhi hasil belajar siswa itu sendiri. Intinya siswa mengalami kerugian baik secara fisik maupun mental, karena fungsi belajar itu adalah untuk memperoleh perubahan pada aspek kejiwaan. Penelitian ini sesuai dengan penelitian Xu and Zhou (2018) yang mengungkapkan "The results of this study indicate that there is a significant association between smog and behavior of high school students, and that air quality affects many facets of student life such as their health, social behavior, mood, attitude, outdoor activities and academic performance." Maksudnya adalah ada hubungan yang signifikan antara kabut asap dan perilaku siswa sekolah menengah, dan kualitas udara itu mempengaruhi banyak segi kehidupan siswa seperti kesehatan mereka, perilaku sosial, suasana hati, sikap, kegiatan di luar ruangan dan kinerja akademik.

\section{Simpulan}

Hasil penelitian tentang dampak kabut asap terhadap kinerja usaha pedagang pasar di Kota Rengat Kabupaten Indiragiri Hulu, Provinsi Riau dapat dibuat kesimpulan sebagai berikut: (1) Kesehatan para pedagang pasar Kota Rengat terganggu karena adanya kabut asap yang tebal sehingga mempengaruhi aktivitas perdagangan itu sendiri. (2) Pendapatan pedagang-pedagang pasar Kota Rengat menjadi menurun karena menurunnya keinginan masyarakat untuk berbelanja di pasar disebabkan adanya rasa khawatir terpapar kabut asap yang dapat menyebabkan penyakit ISPA dan gangguan kesehatan lainnya. (3) Lingkungan pasar Kota Rengat terdampak kasbut asap mempengaruhi aktivitas kehidupan pedagang sehari-hari. Biasanya para pedagang sudah menggelar dagangannya mulai dari awal pagi, karena kabut asap sebagian besar pedagang sering datang terlambat ke pasar (kesiangan). (3) Pendidikan siswa dari keluarga pedagang pasar di Kota Rengat juga terkena dampak kabut asap sehingga harus diliburkan hingga kondisi cuaca normal kembali. Karena hal tersebut siswa banyak ketinggalan materi dan harus memaksakan diri untuk mengejar ketertinggalan tersebut dengan cara menambah jam dan tugas belajar yang banyak di luar kapasitas berpikir siswa.

\section{Daftar Pustaka}

Buka, I., Koranteng, S., \& Osornio-Vargas, A. R. (2006). The effects of air pollution on cultural heritage. The effects of air pollution on the health of children, 11(8), 513-516. https://doi.org/10.1007/978-0-387-84893-8

Kochi, I., Donovan, G. H., Champ, P. A., \& Loomis, J. B. (2010). The economic cost of adverse health effectsfrom wildfire-smoke exposure: A review. International Journal of Wildland Fire, 19(7), 803-817. https://doi.org/10.1071/WF09077

Lang, I. A., Llewellyn, D. J., Langa, K. M., Wallace, R. B., Huppert, F. A., \& Melzer, D. (2008). Neighborhood Deprivation, Individual Socioeconomic Status, and Cognitive Function in Older People: Analyses from the 
Ivalaina Astarina et al, Dampak Kabut Asap Terhadap Kinerja Usaha Pedagang Pasar di Kota Rengat Kabupaten Indragiri Hulu Provinsi Riau

English Longitudinal Study of Ageing. Journal of the American Geriatrics Society, 56(2), 191-198. https://doi.org/10.1111/j.1532-5415.2007.01557.x

Li, L., Lei, Y., Pan, D., Yu, C., \& Si, C. (2016). Economic evaluation of the air pollution effect on public health in China's 74 cities. SpringerPlus, 5(1), 1-16. https://doi.org/10.1186/s40064-016-2024-9

Liu, J. C., Mickley, L. J., Sulprizio, M. P., Dominici, F., Yue, X., Ebisu, K., ... Bell, M. L. (2016). Particulate air pollution from wildfires in the Western US under climate change. Climatic Change, 138(3), 655-666. https://doi.org/10.1007/s10584-016-1762-6

Luo, Y., Chen, H., Zhu, Q. U. A., Peng, C., Yang, G., Yang, Y., \& Zhang, Y. (2014). Relationship between air pollutants and economic development of the provincial capital cities in China during the past decade. PLOS ONE, 9(8), 1-14. https://doi.org/10.1371/journal.pone.0104013

Putri, R. (2015). Dampak Kabut Asap Pada Kehidupan Masyarakat Di Kelurahan Tuah Karya Kecamatan Tampan Kota Pekanbaru Provinsi Riau. Jurnal Spasial, 2(1), 43-50. https://doi.org/10.22202/js.v2i1.1586

Reid, C. E., Brauer, M., Johnston, F. H., Jerrett, M., Balmes, J. R., \& Elliott, C. T. (2016). Critical review of health impacts of wildfire smoke exposure. Environmental Health Perspectives, 124(9), 1334-1343. https://doi.org/10.1289/ehp.1409277

Xu, K. X., \& Zhou, X. (2018). Psychological Effects and Behavioral Impact of Smog on High School Youths. Journal of Environmental Research, 2(7), 1-7.

Harsono, Fitri Haryanti. 30 Juli 2019. Puncak Musim Kemarau Diprediksi Terjadi pada Agustus 2019. https://www.liputan6.com/health/read/4025571/puncak-musim-kemarau-diprediksi-terjadi-pada-agustus-2019. Diakses 15 September 2019.

Ikhbal, Andi Mohammad. 18 September 2019. BMKG Pantau 1.313 Titik Panas, Paling Banyak Jambi, Sumsel dan Riau. https://www.inews.id/daerah/regional/bmkg-pantau-1313-titik-panas-paling-banyak-jambi-sumsel-danriau. Diakses 19 September 2019

Raharjo, Budi. 23 September 2019. Kualitas Udara Riau Berbahaya. https://nasional.republika.co.id/berita/py9e9k415/kualitas-udara-riau-berbahaya. Diakses 25 September 2019

Tanjung, Idon. 15 September 2019. Kemarau di Riau Berlangsung Hingga Oktober 2019, Kabut Asap Makin Pekat. https://regional.kompas.com/read/2019/09/15/07010671/kemarau-di-riau-berlangsung-hingga-oktober-2019kabut-asap-masih-pekat. Diakses 16 September 2019. Diakses 16 September 2019 